\title{
Taxation and Budget Reform Commission (TBRC) Statutory Recommendation: Sales and Use Tax Exemption Review Committee ${ }^{1}$
}

Rodney L. Clouser ${ }^{2}$

A series of 16 fact sheets has been written on statutory and constitutional proposals adopted by the Taxation and Budget Reform Commission (TBRC). The publications in this series can be accessed at http://edis.ifas.ufl.edu. Fact sheets FE733 through FE741 address statutory changes and fact sheets FE742 through FE748 address constitutional amendments. These fact sheets should not be considered as an all-inclusive assessment of the statutory or constitutional changes recommended by the Taxation and Budget Reform Commission. Some details of proposed changes may not have been discussed due to space limitations. These fact sheets are not intended as a replacement for personal knowledge about actual or proposed changes but are a guide to inform the public on the issues.

\section{Introduction}

The Taxation and Budget Reform Commission (TBRC) has made a statutory recommendation to the Florida Legislature concerning a sales and use tax exemption review committee. The TBRC recommended establishment of a joint legislative sales and use tax exemption review committee. The committee would be charged with reviewing exemptions from Florida's general state sales and use taxes.

\section{TBRC Recommendations}

The TBRC has recommended the creation of a new section of the Florida Statutes (Section 11.95). The proposal establishes a joint legislative sales and use tax exemption review committee composed of 18 members (half appointed by the Florida Senate President and half appointed by the Speaker of the House). The committee's principle task would be reviewing exemptions from Florida's general state sales and use taxes.

After initial establishment and organization of the review committee, future committees would serve two-year terms. In even numbered years, the committee chair would be appointed by the Senate President and the vice-chair by the Speaker of House. In odd numbered years, these roles and appointments would be reversed. All committee meetings require public notice and the meetings themselves must be open to the public.

1. This is EDIS document FE739, a publication of the Food and Resource Economics Department, Florida Cooperative Extension Service, Institute of Food and Agricultural Sciences, University of Florida, Gainesville, FL. Published July 2008. Please visit the EDIS website at http://edis.ifas.ufl.edu.

2. Rodney L. Clouser, professor and extension public policy specialist of the Food and Resource Economics Department, Florida Cooperative Extension Service, Institute of Food and Agricultural Sciences, University of Florida, Gainesville, FL.

The Institute of Food and Agricultural Sciences (IFAS) is an Equal Opportunity Institution authorized to provide research, educational information and other services only to individuals and institutions that function with non-discrimination with respect to race, creed, color, religion, age, disability, sex, sexual orientation, marital status, national origin, political opinions or affiliations. U.S. Department of Agriculture, Cooperative Extension Service, University of Florida, IFAS, Florida A. \& M. University Cooperative Extension Program, and Boards of County Commissioners Cooperating. Larry Arrington, Dean 
Sales and use taxes to be reviewed by the committee are taxes imposed under Chapter 212, Florida Statutes. Exemptions are defined as sales, use, or other transactions that would normally be taxed under provisions of Chapter 212 if not for provisions exempting that taxation. Items excluded from taxation under Chapter 212 would not be subject to review by the committee. These include sales not considered as retail, export sales, items sold for resale, sales or use of real and intangible property, isolated sales, and the sale or use of services except those identified under Chapter 212. Staff analysis identifies services subject to sales taxation under Chapter 212 as detective, burglar protection, and other protective services, and non-residential cleaning and pest control services.

The TBRC's recommendation establishes criteria to evaluate sales and use tax exemptions. Those criteria include equity, compliance, pro-competitiveness, neutrality, stability, integration, and public purpose. The TBRC proposes definitions for these criteria. The proposal can be accessed online at http://www.floridatbrc.org/pdf/SR29C1_final.pdf.

Using the seven criteria, the review committee would be charged with recommending, retaining, modifying, or repealing the exemption. Modification or repeal of the exemption would require a majority vote of the committee. The order in which the committee reviews exemptions is left to the judgment of the committee. The recommended exemption review cycle is a three-year cycle, and the committee would be expected to review approximately one-third of the exemptions each year. No exemption could be reviewed more than once during the three-year review cycle. Any new exemptions adopted by the legislature would not be subject to review for six years after the exemption took effect. A new three-year review cycle would occur every ten years.

Recommendations for the modification or repeal of exemptions would be made to the legislature each year of the three-year review cycle 30 days prior to the beginning of the next legislative general session. Legislative bills for the repeal or modification of sales and use tax exemptions would be filed in both houses of the legislature at the next regular session, and these bills would not be subject to filing limits or reference to a committee. These modifications or suggestions for repeal would then be subject to a vote by each house of the legislature. If the legislature repeals an exemption, the repeal would not take effect for at least 180 days after passage of the repeal.

\section{Impact of Proposed Statutory Change}

The impact of the proposed statutory change is unknown. According to the State (2007 Florida Tax Handbook), there are in excess of 240 sales and use tax exemptions in Florida. A precise estimate of the cost of sales and use tax exemptions covered under Chapter 212 is estimated at something less than $\$ 12$ billion. The number of exemptions that would be modified or repealed is unknown although some believe that a formal review process might speed up the number of sales and use tax exemptions repealed or modified.

There have been long-standing disputes among individuals, groups, organizations and businesses that state sales and use tax exemptions are:

- Inequitable - there are not similar tax burdens for people with similar circumstances or "equal treatment of equals."

- Regressive-people with lower income levels should not be paying a greater burden of income in taxes.

- Anti-business-taxes are not sensitive to national and international conditions and do not encourage investment by individuals or business in the state.

- Unstable-revenues are "lumpy" because the state is so dependent upon sales taxes to fund general government. As the national and state economy goes, so goes sales and use tax collections. This makes it difficult to fund programs adequately in the state for the long term.

- Do not serve a public purpose - this could include economic development, job creation, business expansion and retention, and economic diversification within the state. 
Will creation of this review committee solve these problems? Possibly, but the primary benefit may be that it encourages the review of exemptions that do not meet the criteria suggested in the statutory revisions. In a state that seems frequently challenged in terms of state revenue needs, this might prove beneficial in funding state programs for the long term, and the plan appears to have the potential to generate several billions of dollars. However, many Florida residents, organizations, and businesses are opposed to raising any new revenue dollars whether it is from taxes, imposed fees, or repeal of sales and use tax exemptions. They would argue that Florida state government is "big" enough and needs to learn to operate within its means.

Certainly, if this statutory recommendation by the TBRC is approved by the legislature, those who are purchasing goods exempt from the sales and use tax will lobby tirelessly to maintain those exemptions. Considerable amounts of money will be expended to maintain these exemptions. Of course, there will also be costs by the Florida Department of Revenue to have these taxes collected if the sales or use tax is modified or repealed. All residents should keep in mind that a significant amount of sales taxes is paid by the 80 plus million tourists/visitors that come to Florida each year and therefore are not paid for by state residents. Any sales or use taxes repealed or modified will affect Florida on many levels.

\section{Summary}

Although the statutory recommendations have been made by the TBRC, and in some instances with specific dates to become effective, the Florida Legislature and the Governor are not bound to the effective dates or the recommendations. Before these recommendations become law, they require approval of both the Florida Senate and House, and approval by the Governor. Citizens interested in the specific recommendations will need to follow the progress of the issue through the legislative process.

Additionally, there is no time limit for action by the legislature on the TBRC recommendations and they can be introduced in future legislative sessions if not passed during the current session.
It is also interesting to note that efforts similar to the TBRC recommendation have been introduced previously before the legislature and have failed to be passed.

\section{References}

Florida Senate. 2007. 2007 Florida Tax

Handbook. Florida Senate, Tallahassee, FL.

Florida Taxation and Budget Reform Commission. 2008. SR29C1: an act relating to the joint legislative sales and use exemption review committee. TBRC, Tallahassee, FL (April). http://www.floridatbrc.org/pdf/SR29C1_final.pdf

Florida Taxation and Budget Reform Commission. 2008. CS/SR 29 Staff Analysis and Economic Impact Statement. TBRC, Tallahassee, FL (April). http://www.floridatbrc.org/pdf/ SR29ApprovedFinal.pdf

Florida Taxation and Budget Reform Commission. 2008. Transmittal letter. TBRC, Tallahassee, FL. http://www.floridatbrc.org/pdf/ 3_18_08TransmittalLtrSR29.pdf

State of Florida. 2008. Taxes on sales, use and other transactions. Chapter 212, Florida Statutes, Florida Legislature, Tallahassee, FL. http://www.flsenate.gov/Statutes/ index.cfm?App_mode=Display_Statute $\& U R L=C h 02$ $\underline{12 /}$

$\underline{\text { tit10212.htm } \& \text { StatuteYear }=2007 \& \text { Title }=\% 2 \mathrm{D} \% 3 \mathrm{E} 200}$ 7\%2D\%3EChapter\%20212 